\title{
Use of zebrafish models to investigate rare human disease
}

\author{
Kathryn Isabel Adamson, ${ }^{1}$ Eamonn Sheridan, ${ }^{2}$ Andrew James Grierson ${ }^{1,3}$
}

${ }^{1}$ Sheffield Institute for

Translational Neuroscience, University of Sheffield, Sheffield, UK

${ }^{2}$ School of Medicine, University of Leeds, Leeds, UK ${ }^{3}$ Department of Neuroscience, University of Sheffield, Sheffield, UK

\section{Correspondence to}

Dr Andrew James Grierson, Sheffield Institute for Translational Neuroscience, Sheffield, S10 2HQ, UK: a.j.grierson@sheffield.ac.uk

Received 27 February 2018 Revised 2 July 2018

Accepted 4 July 2018

Published Online First 31 July 2018

Check for updates

(C) Author(s) (or their employer(s)) 2018. No commercial re-use. See rights and permissions. Published by BMJ.

To cite: Adamson $\mathrm{KI}$

Sheridan E, Grierson AJ.

$J$ Med Genet

2018;55:641-649

\section{ABSTRACT}

Rare diseases are collectively common and often extremely debilitating. Following the emergence of nextgeneration sequencing (NGS) technologies, the variants underpinning rare genetic disorders are being unearthed at an accelerating rate. However, many rare conditions lack effective treatments due to their poorly understood pathophysiology. There is therefore a growing demand for the development of novel experimental models of rare genetic diseases, so that potentially causative variants can be validated, pathogenic mechanisms can be investigated and therapeutic targets can be identified. Animal models of rare diseases need to be genetically and physiologically similar to humans, and well-suited to large-scale experimental manipulation, considering the vast number of novel variants that are being identified through NGS. The zebrafish has emerged as a popular model system for investigating these variants, combining conserved vertebrate characteristics with a capacity for large-scale phenotypic and therapeutic screening. In this review, we aim to highlight the unique advantages of the zebrafish over other in vivo model systems for the large-scale study of rare genetic variants. We will also consider the generation of zebrafish disease models from a practical standpoint, by discussing how genome editing technologies, particularly the recently developed clustered regularly interspaced repeat (CRISPR)/ CRISPR-associated protein 9 system, can be used to model rare pathogenic variants in zebrafish. Finally, we will review examples in the literature where zebrafish models have played a pivotal role in confirming variant causality and revealing the underlying mechanisms of rare diseases, often with wider implications for our understanding of human biology.

\section{THE IMPORTANCE OF RESEARCHING RARE GENETIC DISEASES}

Rare genetic diseases commonly manifest as chronically debilitating illnesses, which often dramatically diminish life expectancy and quality of life. ${ }^{1}$ Although such diseases are individually rare, defined as having a prevalence lower than 1 in $2000,{ }^{2}$ the term 'rare disease' has been ascribed to over 6000 distinct disorders. ${ }^{1}$ Collectively, these conditions affect around 30 million people in the European Union alone, ${ }^{1}$ thus posing a tremendous societal burden. ${ }^{3}$

Approximately $80 \%$ of rare diseases have a genetic aetiology. ${ }^{4}$ The advent of next-generation sequencing (NGS) technologies has made it possible to rapidly and cost-effectively sequence large regions of DNA in an unbiased manner, which has been especially advantageous for diagnosing rare genetic diseases. This has triggered rapid progress in the identification of their causative mutations in recent years, ${ }^{5}$ and several collaborative large-scale initiatives, comprising national and international networks of clinicians and researchers, have now been established with the aim of accelerating rare disease gene discovery by NGS (table 1).

Despite these advances, treatments for most rare diseases remain scarce. ${ }^{6}$ For 'ultrarare' diseases, in which candidate variants have only been identified in a handful of individuals within a single pedigree, validation of pathogenicity can be challenging. Additionally, because translational research efforts have historically been more focused on common disorders, ${ }^{7}$ the underlying mechanisms contributing to rare diseases often remain poorly understood, even where the genetic aetiology has been confirmed.

Considering the growing number of candidate rare disease variants being identified through NGS, there is an increasing need for research into these diseases. Such research will promote insight into their pathogenic mechanisms, helping to accelerate therapeutic development and alleviate the collective burden created by rare illnesses. Moreover, research to reveal the causes of rare conditions can often illuminate fundamental pathways governing human biology, which may advance our understanding of more common disorders. ${ }^{8}$

For example, the rare metabolic condition, Gaucher's disease, is caused by homozygous mutations in $G B A$, resulting in deficiency of the $\beta$-glucocerebrosidase protein. ${ }^{9}$ Interestingly, some heterozygous $G B A$ variants confer risk for the comparatively common neurodegenerative disorder, Parkinson's disease. ${ }^{10}$ This genetic link between two clinically disparate diseases has revealed a role for $\beta$-glucocerebrosidase deficiency in some forms of Parkinson's disease. ${ }^{11}$ Because of this, clinical trials of ambroxol, a pharmaceutical compound that restores the trafficking and enzymatic activity of $\beta$-glucocerebrosidase, ${ }^{12}$ are currently underway for Parkinson's disease (NCT02941822; NCT02914366).

\section{MODELLING RARE GENETIC DISEASES}

Progress in the study of rare diseases necessitates the development of experimental models in which candidate variants can be validated and disease mechanisms can be explored. Information about the functionality of variants can often be gleaned using in vitro or cellular approaches, or through analysis of patient tissue samples. ${ }^{13-16}$ However, these approaches are insufficient to demonstrate pathogenicity at the whole organism level. For 
many rare diseases, in vivo models are therefore required to confirm causality, ${ }^{17-19}$ especially for neurological disorders where pathologically relevant patient tissue is often inaccessible, or for conditions where interactions between multiple cell types or organ systems are required for a disease phenotype to manifest. A caveat to this is that some mutations may have species-specific effects, so the presence or absence of a phenotype in a model organism must be interpreted carefully. For example, several murine cystic fibrosis models fail to accurately recapitulate key respiratory features of the human phenotype, despite harbouring the pathogenic deletion mutation present in most patients. ${ }^{20} 21$

Besides the capacity to validate candidate genes, in vivo models of rare disease offer further opportunities to dissect disease mechanisms within biologically relevant systems, and to explore the phenotypic consequences of therapeutic intervention. It is important that this can be done at scale, considering initiatives such as the 100000 Genomes Project, which aim to reveal the genetic causes of rare diseases in thousands of patients. ${ }^{22}$

In vivo models for rare genetic disease must be genetically tractable, with a fully sequenced genome that shares substantial homology with the human genome and an amenability to genetic manipulation on a whole organism scale. Historically, the mouse (Mus musculus) has been considered a pre-eminent model organism for human genetic disease, ${ }^{23}$ but mice would be impractical for validating the large number of candidate variants that are likely to be identified through large-scale rare disease programmes, due to their high husbandry costs and small litter sizes. Invertebrates, such as Drosophila melanogaster and Caenorhabditis elegans, are also commonly used as models for human genetic diseases. ${ }^{24} 25$ These are better-suited to largescale analyses, ${ }^{26}{ }^{27}$ but their evolutionary distance from humans and resulting physical differences can make them a less relevant system in which to investigate the physiological consequences of disease-linked mutations and therapeutic interventions.

\section{ZEBRAFISH AS AN EMERGING MODEL ORGANISM FOR RARE GENETIC DISEASES}

In recent years, the zebrafish (Danio rerio) has become an attractive model organism for translational research. Zebrafish uniquely combine many of the genetic and physiological advantages of mammalian models with the high-throughput capabilities and experimental manipulability of invertebrate models. ${ }^{28}$ Their growing popularity is reflected by a continued increase

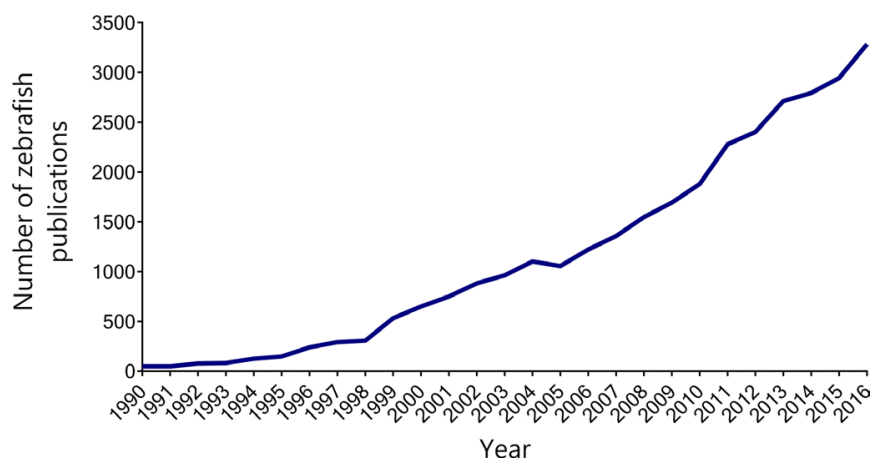

Figure 1 The use of zebrafish in biomedical research articles has been rising since the early 1990s. The line graph shows the number of publications indexed by PubMed under the term 'zebrafish' each year between 1990 and 2016. Raw data obtained from Medline Trend (http:// dan.corlan.net/medline-trend.html).

in the use of zebrafish in biomedical research publications (figure 1).

\section{Genetic and physiological conservation}

The zebrafish genome possesses considerable homology with the human genome, with orthologues having been identified for approximately $70 \%$ of human genes. ${ }^{29}$ Zebrafish are also highly genetically tractable, and tools for generating genetically modified zebrafish models continue to be developed and optimised. ${ }^{30}$

Anatomically and physiologically, the zebrafish is more distantly removed from humans than the mouse. Consequently, it can be more challenging to model genetic diseases affecting structures that are absent in fish, such as the lungs. ${ }^{31}$ Nonetheless, the straightforward vertebrate architecture of the zebrafish enables the simplified study of disease in numerous organ systems and structures that are common to both zebrafish and humans. For example, the zebrafish has successfully been used to model genetic diseases affecting the human cardiovascular, ${ }^{32}$ nervous, ${ }^{33}$ visual, ${ }^{34}$ renal $^{35}$ and muscular systems, ${ }^{36}$ among others.

\section{Study of genes essential for mammalian placental development}

As a non-placental vertebrate, the zebrafish allows us to study phenotypes linked to genes that are essential for mammalian

Table 1 National and international collaborative networks aiming to accelerate research into rare genetic diseases

\begin{tabular}{|c|c|c|c|c|}
\hline Programme/network name & Locations & Active years & Aims and specific disease interests & Key publications \\
\hline $\begin{array}{l}\text { Finding the Genetic Basis of } \\
\text { Learning Disability study }\end{array}$ & $\begin{array}{l}\text { Based at the Cambridge Institute for Medical Research (UK) } \\
\text { Collaborations with Wellcome Trust Sanger Institute (UK), } \\
\text { Greenwood Genetic Center (USA), University of Adelaide } \\
\text { (Australia) and University of Newcastle (Australia) }\end{array}$ & 2001-present & $\begin{array}{l}\text { Identifying genetic causes of } \mathrm{X} \text { linked } \\
\text { intellectual disability }\end{array}$ & 87 \\
\hline $\begin{array}{l}\text { Deciphering Developmental } \\
\text { Disorders study }\end{array}$ & $\begin{array}{l}\text { Collaborations across } 24 \text { Regional Genetics Services (UK and } \\
\text { Ireland) and Wellcome Trust Sanger Institute (UK) }\end{array}$ & $2011-2016$ & $\begin{array}{l}\text { Identifying genetic causes of } \\
\text { developmental disorders }\end{array}$ & $88-90$ \\
\hline $\begin{array}{l}\text { Finding of Rare Disease Genes } \\
\text { Canada Consortium }\end{array}$ & $\begin{array}{l}\text { Network of } 21 \text { genetics centres and } 3 \text { science and } \\
\text { technology innovation centres across Canada, with ad hoc } \\
\text { international collaborations across } 17 \text { additional countries }\end{array}$ & $2011-2013$ & $\begin{array}{l}\text { Identifying genes associated with rare } \\
\text { monogenic diseases with paediatric } \\
\text { onset }\end{array}$ & 91 \\
\hline $\begin{array}{l}\text { International Rare Diseases } \\
\text { Research Consortium }\end{array}$ & $\begin{array}{l}\text { International network of researchers and organisations with } \\
\text { an interest in rare disease research }\end{array}$ & 2011-present & $\begin{array}{l}\text { Contributing to the development of } \\
\text { novel rare disease therapies and the } \\
\text { means to uncover the genetic causes of } \\
\text { rare diseases }\end{array}$ & 92 \\
\hline Undiagnosed Diseases Network & $\begin{array}{l}\text { Network of clinical and scientific sites across the USA, } \\
\text { coordinated by Harvard Medical School }\end{array}$ & 2014-present & $\begin{array}{l}\text { Accelerating identification of genetic } \\
\text { causes of rare diseases, with use of } \\
\text { Drosophila and zebrafish models to } \\
\text { validate candidate genes }\end{array}$ & 9394 \\
\hline
\end{tabular}


embryogenesis. Investigations into the pathophysiology of rare human diseases caused by mutations in the von Hippel-Lindau (VHL) tumour suppressor gene were hindered by the fact that $V h l$ knockout mice develop placental defects, resulting in embryonic lethality. ${ }^{37}$ Mice harbouring conditional null mutations or disease-specific point mutations are viable and have been used to study aspects of protein function and pathophysiology, but they lack important phenotypic characteristics of human VHL-associated disease. ${ }^{3839}$ Given these limitations, van Rooijen et al sought to generate zebrafish models harbouring null mutations in $v h l_{.}{ }^{40}$ These mutants are viable up to larval stages, and closely recapitulate the phenotype of human Chuvash polycythaemia, caused by a homozygous recessive (p. R200W) mutation in VHL. Notably, the zebrafish mutants exhibited disease-associated phenotypes that were not observed in earlier mouse models, exemplifying the utility of this system for modelling loss-of-function (LOF) phenotypes that can be more challenging to study in mammalian systems.

\section{Investigation of developmental processes}

The zebrafish additionally offers unparalleled opportunities for the investigation of fundamental developmental processes. Three-quarters of rare diseases arise during childhood and 30\% of rare disease patients do not survive past their fifth birthday, ${ }^{4}$ so perturbed developmental processes are likely to be implicated in the pathogenesis of many rare conditions. Zebrafish embryos develop externally and rapidly from the onecell stage, and morphogenesis of most major organ systems is complete within 48 hours of fertilisation. ${ }^{41}$ These characteristics, combined with their optical transparency as embryos, and the array of reporter lines and imaging techniques available for detailed visualisation of developmental and physiological processes, ${ }^{42-44}$ make zebrafish immensely useful for exploring the effects of rare disease-linked mutations on vertebrate development.

\section{Large-scale phenotypic screening}

Zebrafish are also amenable to large-scale analyses. As adults, their small size and inexpensive husbandry mean that they can be housed in large numbers, but their advantages in large-scale applications are especially apparent at embryonic and larval stages. A pair of adult zebrafish can produce hundreds of eggs in a single clutch, and the resulting embryos and larvae are sufficiently small that they can be housed in 96-well or 384-well plates, ${ }^{45}$ allowing phenotypic analysis using high-throughput microscopy and behavioural analysis systems. ${ }^{46}{ }^{47}$ Soluble compounds can also be dissolved directly into the medium in which the embryos are housed, providing a convenient platform for rapid and efficient screening of small molecule phenotype modifiers once relevant pathophysiological mechanisms have been identified. ${ }^{47}$ This positions the zebrafish as an unrivalled tool combining the scalability of in vitro and cell-based assays with a multidimensional capacity to explore disease mechanisms, phenotypes and therapeutic strategies within a living vertebrate.

\section{GENERATING ZEBRAFISH MODELS OF RARE GENETIC DISEASES}

Over time, various approaches have been used to model human genetic diseases in zebrafish. Summarised in table 2, these encompass strategies for generating stable mutant lines by random mutagenesis or targeted gene editing, ${ }^{48-52}$ as well as methods for transient interrogation of the effects of altered gene expression. $^{53-55}$

\section{Generation of stable zebrafish disease models}

\section{Random mutagenesis}

Traditionally, genetic manipulation of zebrafish has focused on random mutagenesis using chemical mutagens such as N-ethyl-N-nitrosourea, or retroviral-mediated insertional methods. ${ }^{4849}$ Mutations in genes of interest can then be identified, and stable mutant lines can subsequently be generated. ${ }^{5657}$ This has taken place on a large scale and huge libraries of stable mutants for numerous zebrafish genes are now available. ${ }^{58}$ However, mutants are not available for every gene and this method also does not enable specific disease-associated mutations to be modelled, limiting its value for testing the pathogenicity of individual candidate variants.

\section{Targeted gene-editing}

More recently, powerful methods involving the use of engineered nucleases, including zinc finger nucleases (ZFNs), transcription activation-like effector nucleases (TALENs) and the clustered regularly interspaced repeat (CRISPR)/CRISPR-associated protein 9 (Cas9) system have been employed to generate stable models of human disease, enabling targeted mutations to be created in specific zebrafish orthologues of interest..$^{50-52}$ Both ZFNs and TALENs require generation of a tailored protein component for each target locus, which can be a costly and laborious process, making these systems less compatible with largescale applications. ${ }^{59}$ In contrast, the CRISPR/Cas9 system relies on recognition of the target site by a custom guide RNA (gRNA) molecule, and simply requires the design of a single oligonucleotide for each target site.

\section{Using CRISPR/Cas9 technology to model rare genetic diseases in zebrafish}

The CRISPR/Cas9 system has therefore become the tool of choice for generating stable models of human genetic diseases in recent years. A mechanistic overview of the classical CRISPR/ Cas9 system in the context of disease modelling is shown in figure 2. Most successes from CRISPR-mediated gene modification in zebrafish have arisen from the generation of frameshift null alleles through non-homologous end-joining (NHEJ)-mediated repair of CRISPR-induced DNA breaks. ${ }^{19} 1960$ This is useful for generating models of human disease occurring due to LOF alleles and work to further improve the mutagenesis efficiency of this method in zebrafish is ongoing.

It may be desirable to introduce specific disease-associated mutations, particularly where complete LOF alleles are lethal or a variant is predicted to act through a gain-of-function mechanism. Knock-in of specific mutations and exogenous DNA sequences has been achieved in zebrafish through both homology-independent and homology-directed repair (HDR), ${ }^{61-64}$ but this approach is currently less efficient than generation of LOF alleles. ${ }^{61}$

Many genetic diseases are caused by missense mutations, which generally arise from single base-pair substitutions. Novel CRISPR/Cas9-derived gene editing tools, known as base editors, ${ }^{65}$ have recently been developed, allowing targeted deaminase-mediated conversion of a single base-pair of interest to another without requiring DNA cleavage. Base editors are currently being assessed for their potential to facilitate modelling of point mutations in various systems, including zebrafish. ${ }^{65-68} \mathrm{~A}$ limitation of this approach is that the base-pair of interest must be located within an optimal window of proximity to a protospacer adjacent motif (PAM). However, efforts are currently underway to overcome this through the development of Cas9 
Table 2 Summary of methods for generating stable and transient zebrafish models of genetic human diseases

\begin{tabular}{|c|c|c|c|c|}
\hline Technique & Mechanism & Required components & $\begin{array}{l}\text { Advantages for modelling rare } \\
\text { genetic diseases in zebrafish }\end{array}$ & $\begin{array}{l}\text { Limitations for modelling rare } \\
\text { genetic diseases in zebrafish }\end{array}$ \\
\hline \multicolumn{5}{|l|}{ Stable models } \\
\hline $\begin{array}{l}\text { ENU-mediated } \\
\text { mutagenesis }\end{array}$ & Random mutagenesis & $\begin{array}{l}\text { Database of mutants that have already } \\
\text { been generated by ENU-mediated } \\
\text { random mutagenesis }\end{array}$ & $\begin{array}{l}\text { If LOF mutants for genes of } \\
\text { interest are available, this } \\
\text { abrogates need to generate a } \\
\text { new model }\end{array}$ & $\begin{array}{l}\text { Mutants for genes of interest are } \\
\text { not always available. Outcrossing } \\
\text { is often required to generate a } \\
\text { stable model. }\end{array}$ \\
\hline $\begin{array}{l}\text { Retroviral-mediated } \\
\text { insertional mutagenesis }\end{array}$ & Random mutagenesis & $\begin{array}{l}\text { Database of mutants that have already } \\
\text { been generated by retroviral-mediated } \\
\text { insertional mutagenesis }\end{array}$ & $\begin{array}{l}\text { If LOF mutants for genes of } \\
\text { interest are available, this } \\
\text { abrogates need to generate a } \\
\text { new model }\end{array}$ & $\begin{array}{l}\text { Mutants for genes of interest are } \\
\text { not always available. Outcrossing } \\
\text { is often required to generate a } \\
\text { stable model. }\end{array}$ \\
\hline $\begin{array}{l}\text { ZFNs+NHEJ-mediated } \\
\text { repair }\end{array}$ & $\begin{array}{l}\text { Creates double-stranded DNA break at } \\
\text { target site, resulting in repair by NHEJ }\end{array}$ & $\begin{array}{l}\text { Multiple DNA-binding zinc finger } \\
\text { peptides (which each recognise } 3 \mathrm{bp} \\
\text { of target DNA) fused to Fokl nuclease } \\
\text { domain }\end{array}$ & $\begin{array}{l}\text { Enables targeted frameshift } \\
\text { mutations to be introduced in } \\
\text { candidate genes of interest }\end{array}$ & $\begin{array}{l}\text { Tailored protein component needs } \\
\text { to be generated for each genomic } \\
\text { target. Outcrossing is often } \\
\text { required to generate a stable } \\
\text { model. }\end{array}$ \\
\hline $\begin{array}{l}\text { CRISPR/Cas9+NHEJ- } \\
\text { mediated repair }\end{array}$ & $\begin{array}{l}\text { Creates double-stranded DNA break at } \\
\text { target site, resulting in repair by NHEJ }\end{array}$ & $\begin{array}{l}\text { Specific } 20 \mathrm{nt} \text { guide RNA } \\
\text { complementary to target site+Cas9 } \\
\text { endonuclease }\end{array}$ & $\begin{array}{l}\text { Enables targeted frameshift } \\
\text { mutations to be introduced in } \\
\text { candidate genes of interest. } \\
\text { gRNAs can easily be designed for } \\
\text { different targets. LOF models can } \\
\text { be efficiently generated through } \\
\text { NHEJ-mediated repair }\end{array}$ & $\begin{array}{l}\text { Some off-target effects are } \\
\text { possible but can be minimised } \\
\text { through appropriate gRNA design. } \\
\text { Outcrossing is often required to } \\
\text { generate a stable model. }\end{array}$ \\
\hline $\begin{array}{l}\text { ZFNs, TALENs or } \\
\text { CRISPR/Cas9+HDR- } \\
\text { mediated repair }\end{array}$ & $\begin{array}{l}\text { Creates double-stranded DNA break at } \\
\text { target site. Simultaneous addition of } \\
\text { DNA repair template results in HDR and } \\
\text { incorporation of specific sequences or } \\
\text { mutations of interest }\end{array}$ & $\begin{array}{l}\text { Zinc finger peptides or customisable } \\
\text { peptide-based DNA-binding } \\
\text { domain fused to Fokl nuclease } \\
\text { domain, or specific } ~ 20 \text { nt guide } \\
\text { RNA complementary to target } \\
\text { site+Cas9 endonuclease (+DNA repair } \\
\text { template containing sequence of } \\
\text { interest) }\end{array}$ & $\begin{array}{l}\text { Allows knock-in of specific } \\
\text { mutations of interest (most } \\
\text { commonly via CRISPR/Cas9) }\end{array}$ & $\begin{array}{l}\text { Currently less efficient than NHEJ- } \\
\text { mediated LOF model generation. } \\
\text { Outcrossing is often required to } \\
\text { generate a stable model. }\end{array}$ \\
\hline Morpholino knockdown & $\begin{array}{l}\text { Blocks mRNA translation or splicing } \\
\text { (post-translational) }\end{array}$ & Synthetic 25 bp oligonucleotide & $\begin{array}{l}\text { Allows for rapid examination of } \\
\text { LOF phenotypes. Could be used } \\
\text { to rapidly obtain evidence to } \\
\text { support causality of LOF candidate } \\
\text { variants }\end{array}$ & $\begin{array}{l}\text { Effects are short-lasting. May be } \\
\text { associated with significant off- } \\
\text { target effects. Cannot be used to } \\
\text { model gain-of-function or patient- } \\
\text { specific mutations. }\end{array}$ \\
\hline $\begin{array}{l}\text { CRISPR/dCas9 (CRISPR } \\
\text { interference) }\end{array}$ & $\begin{array}{l}\text { Blocks transcription (and can be } \\
\text { coupled to transcriptional activators } \\
\text { or repressors to further control gene } \\
\text { dosage) }\end{array}$ & $\begin{array}{l}\text { Specific } \sim 20 \text { nt gRNA complementary } \\
\text { to target site+dCas9 (which can be } \\
\text { fused to a transcriptional activator or } \\
\text { repressor) }\end{array}$ & $\begin{array}{l}\text { Can be used to model both gain } \\
\text { and LOF phenotypes. Has the } \\
\text { potential to be used on a large } \\
\text { scale }\end{array}$ & $\begin{array}{l}\text { Currently not widely used in } \\
\text { zebrafish. Specificity for target site } \\
\text { needs to be established. }\end{array}$ \\
\hline
\end{tabular}

Cas9, CRISPR-associated protein 9; CRISPR, clustered regularly interspaced repeats; dCas9, catalytically inactive Cas9; ENU, N-ethyl-N-nitrosourea; HDR, homology-directed repair; LOF, loss-of-function; NHEJ, non-homologous end joining; TALENs, transcription activation-like effector nucleases; ZFNs, zinc finger nucleases.

base-editing variants recognising alternative PAM sequences, ${ }^{69}$ which could vastly increase the scope for modelling rare genetic diseases linked to point mutations.

\section{Methods for transiently modelling genetic disease in zebrafish}

Transient genetic manipulation of zebrafish may also be useful where complete LOF of a gene of interest is undesirable. This has traditionally been accomplished via morpholino-mediated knockdown of zebrafish orthologues of interest; however, concerns have been raised about the on-target specificity of morpholinos. ${ }^{70}$ CRISPR interference (CRISPRi), another variation on the CRISPR/Cas9 system, can be used to reversibly silence expression of a target gene at the transcriptional level. ${ }^{71}$ The CRISPRi machinery can also be coupled to transcriptional repressors or activators to alter gene dosage, allowing LOF or gain-of-function variants to be reversibly mimicked. ${ }^{72}$ Most examples of the use of this technology have come from cellular experiments, ${ }^{73}$ although CRISPRi has successfully been used to silence gene expression in zebrafish. ${ }^{55}$ As CRISPRi is developed further, it is expected to offer additional possibilities for modelling human genetic diseases in zebrafish. ${ }^{75}$

\section{USING ZEBRAFISH TO MODEL RARE GENETIC DISEASES}

The benefits of the zebrafish as a model for rare genetic disease are illustrated by several examples in the literature. Here, we 


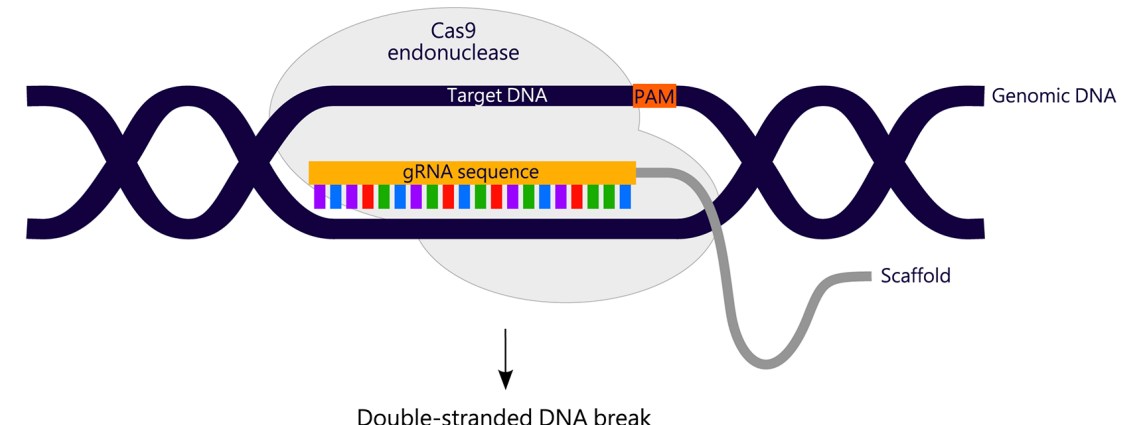

Double-stranded DNA break

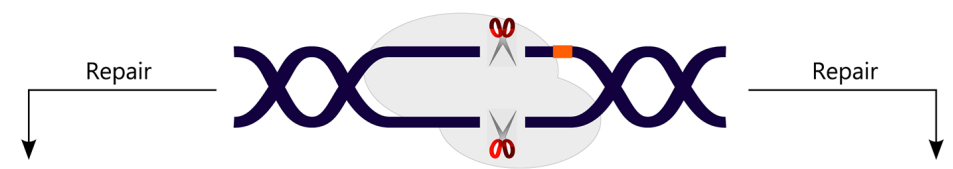

Non-homologous end joining

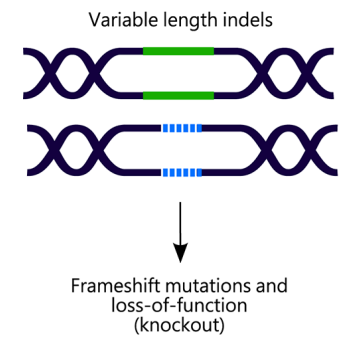

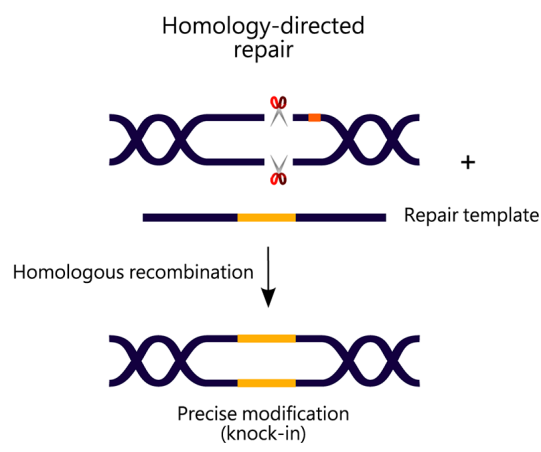

Figure 2 Overview of clustered regularly interspaced repeat (CRISPR)/CRISPR-associated protein 9 (Cas9)-mediated genome editing. A 20-nucleotide guide RNA ( $g R N A$ ) directs Cas9 endonuclease to a chosen genomic target site (also known as the protospacer) immediately upstream of a protospaceradjacent motif (PAM). On binding to the target site, Cas9 cleaves the genomic DNA to create a double-stranded DNA break 3-4 bp upstream of the PAM. Subsequent DNA repair via the non-homologous end joining (NHEJ) or homology-directed repair (HDR) pathways can be exploited to generate disease models through the creation of knockout alleles (to investigate loss-of-function of a gene of interest), or knock-in alleles (to study the consequences of a specific disease-associated mutation). For HDR approaches, a tailored repair template containing the variant of interest is also required.

review examples where zebrafish models of rare diseases have been instrumental in confirming the pathogenicity of candidate variants, for elucidating disease mechanisms, and in the functional annotation of rare disease genes.

\section{Confirming causality of candidate rare disease-associated variants}

The value of zebrafish models in supporting the causality of candidate rare disease variants is exemplified by the identification of several novel genes linked to Hirschsprung disease. Hirschsprung disease is a rare disorder characterised by aberrant development of enteric neurons, resulting in an absence of innervation in parts of the colon. Whole exome sequencing (WES) analysis of 24 trios, comprised of patients with Hirschsprung disease and their parents, led to the discovery of several novel LOF and missense variants in genes with no prior links to either enteric nervous system development or Hirschsprung disease pathogenesis. ${ }^{18}$ Given an absence of clues that would substantiate the pathogenicity of these variants in patients, the authors investigated the effects of LOF of zebrafish orthologues for 12 of these candidate genes on enteric nervous system development. Morpholino knockdown of four of these genes caused a Hirschsprung-like phenotype, comprising absent enteric innervation of the distal intestine at 5 days post-fertilisation. This was complemented by recapitulation of the disease phenotype in CRISPR knockout mutants for the same genes, providing novel evidence to link these genes to Hirschsprung disease. ${ }^{18}$
Increasing understanding of rare disease pathophysiology Zebrafish models have also successfully been used to reveal pathogenic mechanisms in rare genetic diseases. DiamondBlackfan anaemia (DBA) is a rare disorder affecting red blood cell production, which often arises due to mutations in ribosomal proteins. Mutations in RPS19, encoding the ribosomal protein S19, account for most DBA cases. To clarify the contribution of ribosomal protein deficiency to the phenotype observed in patients with DBA, TALENs were used to generate a knockout model for the zebrafish orthologue, $r p s 19 .{ }^{76}$ This model mimics pathogenic features of DBA, including impaired haematopoiesis and p53 activation.

The authors also demonstrated that globin protein production is impaired in rps19-null mutants, with negligible effect observed at the mRNA level. This was replicated in an additional zebrafish model of DBA, harbouring a null mutation in rpl11. By generating a transgenic zebrafish reporter line exhibiting erythroid-specific mCherry expression, they determined that the defective globin production was likely a result of faulty protein production in these cells rather than a pathogenic effect specific to globin genes. ${ }^{76}$

Previously, zebrafish rps19 morphants were treated with L-leucine on the basis of its known stimulatory effects on protein synthesis. ${ }^{77}$ This improved their anaemic phenotype through activation of the mTOR pathway. ${ }^{78}$ Correspondingly, L-leucine treatment of rps19 and rpl11 mutants ameliorated globin protein production with partial phenotypic rescue, suggesting 
that L-leucine may activate translation in erythroid cells. ${ }^{76}$ Here, zebrafish models have progressed understanding of DBA pathophysiology, and present an in vivo system that could be used to further investigate pathogenesis and screen for possible therapeutic modifiers of the disease phenotype.

\section{Functional annotation of rare disease-associated genes}

As well as their specific advantages in relation to the study of rare diseases, zebrafish models of rare genetic conditions can also contribute novel insights into the biological pathways and processes in which rare disease genes are implicated. These findings have value in a translational context and may ultimately improve our understanding of more common disorders.

Identification of a novel pathway involved in human bone formation Members of the vacuolar ATPase (V-ATPase) protein family form multicomponent complexes that are responsible for regulating intracellular and extracellular $\mathrm{pH}$ through acidification. ${ }^{79}$ This acidification process is especially important in osteoclasts, where it critically regulates proper bone resorption. ${ }^{79}$ Accordingly, mice deficient for the V-ATPase gene Atp6i exhibit osteopetrosis (increased bone density), which is underpinned by impaired bone resorption due to deficient extracellular acidification by osteoclasts. ${ }^{80}$ Through the NIH Undiagnosed Diseases Programme, a rare heterozygous mutation in the ATP6V1H gene (encoding another member of the complex) was found to segregate with a phenotype of osteoporosis (reduced bone density) in three generations of a single pedigree. ${ }^{19}$ The human disease-associated mutant ATP6V1H protein was shown to be less stable than the wild-type protein when expressed in HEK cells, suggesting that ATP6V1H haploinsufficiency may contribute to pathogenesis; this was unexpected given the contrasting phenotypes of the patients and Atp $6 i$-null mice. ${ }^{19}$

A zebrafish model harbouring a CRISPR-induced null mutation in atp6v1h was developed to investigate the consequences of loss of ATP $6 \mathrm{~V} 1 \mathrm{H}$ function on bone homeostasis. ${ }^{19}$ At 6 days post-fertilisation, bone mineralisation was reduced in homozygous null mutant embryos compared with wild-type zebrafish and this was not rescued by injection of mRNA harbouring the pathogenic mutation from patients with osteoporosis. Heterozygous mutants exhibited no obvious skeletal defects until adulthood, at which point decreased bone density, volume and surface area became apparent, along with a marked reduction in calcification of the vertebral centrum. Thus, this model recapitulates the osteoporotic phenotype observed in patients with the ATP6V1H mutation and supports a role for ATP6V1H deficiency in the disease process. ${ }^{19}$

The authors additionally explored the pathways linking atp $6 v 1 \mathrm{~h}$ deficiency to aberrant bone homeostasis in their zebrafish model. They discovered that atp $6 v 1 \mathrm{~h}$ deficiency results in elevated transcript levels of the osteoclast marker, matrix metalloproteinase-9 (mmp9). This was also the case for $m m p 13 a$, which is involved in $m m p 9$-mediated control of bone homeostasis. ${ }^{81}$ Corroboration of these findings came through the demonstration that murine $M m p 9$ and $M m p 13$ are also upregulated on Atp6v1h knockdown in mouse osteoclasts. Atp6v1h-deficient osteoclasts displayed increased staining for tartrate-resistant acid phosphatase-a marker of osteoclast activity. This was also observed in sections obtained from heterozygous atp $6 v 1 \mathrm{~h}$ mutant zebrafish, suggesting that LOF of atp $6 v 1 \mathrm{~h}$ results in hyperactivity of osteoclasts, which may be regulated by $m m p 9$ and $m m p 13 a$. Accordingly, treatment of atp6v1h mutant embryos with MMP9 and MMP13 inhibitors rescued the aberrant bone phenotypes, providing evidence to support exploration of MMP9 and MMP13 as therapeutic targets for patients with ATP6V1H deficiency. ${ }^{19}$

Here, a zebrafish model of a rare genetic disease has provided valuable information about the underlying pathophysiology of this condition, revealing potential therapeutic targets. More fundamentally, these investigations have uncovered a novel ATP6V1H-mediated pathway involved in maintaining vertebrate bone homeostasis - a finding that may have implications for more prevalent bone disorders.

Discovery of a key genetic player in the control of human laterality WES analysis of a single consanguineous pedigree led to the identification of a homozygous frameshift mutation in the matrix metalloproteinase-21 (MMP21) gene, segregating with a phenotype of heterotaxia. ${ }^{60}$ The variant was predicted to impair protein function, so to generate evidence to support its pathogenicity, the authors investigated whether LOF of zebrafish $m m p 21$ would also induce a laterality defect.

Morpholino silencing or CRISPR/Cas9-mediated knockout of $m m p 21$ caused cardiac looping defects in zebrafish embryos. Knockdown of $m m p 21$ also led to abnormal expression of the laterality marker, southpaw (spaw), indicating that the looping defects are linked to aberrant control of left-right asymmetry. ${ }^{60}$ This supports the causality of the LOF MMP21 mutation in patients with heterotaxia and demonstrates involvement of MMPs in the establishment of organism polarity.

Further cell-based investigation of the connection between MMP21 and control of laterality revealed that MMP21 likely acts as a negative regulator of the Notch signalling pathway, which is required for establishing left-right asymmetry. ${ }^{82}$ Several target genes of Notch signalling were upregulated in the zebrafish mmp21 morphants, emphasising the contribution of this pathway to MMP21-mediated control of laterality. ${ }^{60}$

Here, a zebrafish model of a rare genetic disease has advanced our understanding of both the underlying pathophysiology of this rare instance of heterotaxia and of the fundamental pathways involved in establishing vertebrate polarity. Specifically, the zebrafish has exposed a previously undiscovered role for MMPs in this process.

\section{CONCLUSION}

Recent advances in DNA sequencing technology and the introduction of large-scale rare disease gene discovery programmes mean that a growing number of candidate disease-associated variants are being rapidly identified for many rare disorders. Combined with the challenging nature of confirming pathogenicity of candidate variants for rare diseases affecting small numbers of patients, this has resulted in a bottleneck in the validation of these variants and elucidation of underlying disease mechanisms. This is a critical hurdle to overcome, as a better understanding of these rare conditions will improve quality of life for rare disease patients by facilitating therapeutic development and will also advance our knowledge of human biology and the mechanisms of more prevalent diseases through the functional annotation of rare disease genes.

Progress in the identification and validation of rare disease variants is of particular relevance to individuals born to consanguineous parents - a population whose risk of congenital anomalies is doubled. ${ }^{83}$ These abnormalities frequently arise from autosomal recessively inherited variants, ${ }^{84}$ and NGS-based approaches are increasingly revealing the rare genetic mutations responsible for diseases in these families. ${ }^{85} 86$ Such conditions 
often present great obstacles with regard to validation of variant pathogenicity; in many cases they are extremely rare, with mutations only reported in a single pedigree.

Here, we present the zebrafish as an ideal in vivo model for addressing this vast pool of candidate rare disease genes. With a highly conserved vertebrate genome and a capacity for largescale genetic manipulation, the zebrafish is well-positioned as a tool for modelling a substantial proportion of rare genetic variants and the scope for modelling these mutations in zebrafish is likely to expand with continued technological advances in the field of CRISPR/Cas9-mediated genome-editing. Indeed, large-scale initiatives, such as the NIH Undiagnosed Diseases Network (table 1), have now been developed with the aim of using zebrafish to assist in the validation of rare disease variants to uncover the genetic causes of previously undiagnosed rare disorders. Moreover, zebrafish can be used in large-scale screening of phenotypes associated with many conserved vertebrate organ systems and structures and they have a capacity for high-throughput testing of therapeutic compounds that is often impractical in other vertebrate model systems. This unique combination of attributes renders the zebrafish unparalleled by other classical model systems in its potential for advancing our understanding of rare genetic diseases.

Contributors KIA and AJG planned and wrote the review. KIA created the Figures. KIA, ES and AJG edited the document.

Funding KIA holds a PhD position funded by the Medical Research Council UK DiMeN Doctoral Training Partnership (Discovery Medicine North: Grant Ref MR/ N013840/1), and is supervised by AJG and ES.

Competing interests None declared.

Patient consent Not required.

Provenance and peer review Not commissioned; externally peer reviewed.

\section{REFERENCES}

1. EURORDIS. Rare diseases: understanding this Public Health Priority. 2005.

2. Boycott KM, Vanstone MR, Bulman DE, MacKenzie AE. Rare-disease genetics in the era of next-generation sequencing: discovery to translation. Nat Rev Genet 2013:14:681-91.

3. Angelis A, Tordrup D, Kanavos P. Socio-economic burden of rare diseases: A systematic review of cost of illness evidence. Health Policy 2015;119:964-79.

4. EURORDIS. What is a rare disease? 2007.

5. Koboldt DC, Steinberg KM, Larson DE, Wilson RK, Mardis ER. The next-generation sequencing revolution and its impact on genomics. Cell 2013;155:27-38.

6. Luzzatto L, Hollak CEM, Cox TM, Schieppati A, Licht C, Kääriäinen H, Merlini G, Schaefer F, Simoens S, Pani L, Garattini S, Remuzzi G. Rare diseases and effective treatments: are we delivering? The Lancet 2015;385:750-2.

7. Shen T, Lee A, Shen C, Lin CJ. The long tail and rare disease research: the impact of next-generation sequencing for rare Mendelian disorders. Genet Res 2015;97:e15.

8. EURORDIS. WHY Research on Rare Diseases. 2010.

9. Brady RO, Kanfer JN, Bradley RM, Shapiro D. Demonstration of a deficiency of glucocerebroside-cleaving enzyme in Gaucher's disease. J Clin Invest 1966;45:1112-5.

10. Goker-Alpan O, Schiffmann R, LaMarca ME, Nussbaum RL, Mclnerney-Leo A, Sidransky E. Parkinsonism among Gaucher disease carriers. J Med Genet 2004;41:937-40.

11. Wong YC, Krainc D. Lysosomal trafficking defects link Parkinson's disease with Gaucher's disease. Mov Disord 2016;31:1610-8.

12. Bendikov-Bar I, Maor G, Filocamo M, Horowitz M. Ambroxol as a pharmacological chaperone for mutant glucocerebrosidase. Blood Cells Mol Dis 2013;50:141-5.

13. Cnossen WR, te Morsche RH, Hoischen A, Gilissen C, Chrispijn M, Venselaar H, Mehdi S, Bergmann C, Veltman JA, Drenth JP. Whole-exome sequencing reveals LRP5 mutations and canonical Wnt signaling associated with hepatic cystogenesis. Proc Natl Acad Sci U S A 2014:111:5343-8.

14. Heidari A, Tongsook C, Najafipour R, Musante L, Vasli N, Garshasbi M, Hu H, Mittal K, McNaughton AJ, Sritharan K, Hudson M, Stehr H, Talebi S, Moradi M, Darvish H, Arshad Rafiq M, Mozhdehipanah H, Rashidinejad A, Samiei S, Ghadami M, Windpassinger C, Gillessen-Kaesbach G, Tzschach A, Ahmed I, Mikhailov A, Stavropoulos DJ, Carter MT, Keshavarz S, Ayub M, Najmabadi H, Liu X, Ropers HH, Macheroux $\mathrm{P}$, Vincent JB. Mutations in the histamine N-methyltransferase gene, HNMT, are associated with nonsyndromic autosomal recessive intellectual disability. Hum Mol Genet 2015;24:5697-710.
15. Miyake N, Fukai R, Ohba C, Chihara T, Miura M, Shimizu H, Kakita A, Imagawa E, Shiina M, Ogata K, Okuno-Yuguchi J, Fueki N, Ogiso Y, Suzumura H, Watabe Y, Imataka G, Leong HY, Fattal-Valevski A, Kramer U, Miyatake S, Kato M, Okamoto N, Sato Y, Mitsuhashi S, Nishino I, Kaneko N, Nishiyama A, Tamura T, Mizuguchi T, Nakashima M, Tanaka F, Saitsu H, Matsumoto N. Biallelic TBCD Mutations Cause Early-Onset Neurodegenerative Encephalopathy. Am J Hum Genet 2016;99:950-61.

16. Dharmat R, Liu W, Ge Z, Sun Z, Yang L, Li Y, Wang K, Thomas K, Sui R, Chen R. IFT81 as a Candidate Gene for Nonsyndromic Retinal Degeneration. Invest Ophthalmol Vis Sci 2017;58:2483-90

17. Yuan Q, Zhao M, Tandon B, Maili L, Liu X, Zhang A, Baugh EH, Tran T, Silva RM, Hecht JT, Swindell EC, Wagner DS, Letra A. Role of WNT10A in failure of tooth development in humans and zebrafish. Mol Genet Genomic Med 2017;5:730-41.

18. Gui H, Schriemer D, Cheng WW, Chauhan RK, Antiňolo G, Berrios C, Bleda M, Brooks AS, Brouwer RW, Burns AJ, Cherny SS, Dopazo J, Eggen BJ, Griseri P, Jalloh B, Le TL, Lui VC, Luzón-Toro B, Matera I, Ngan ES, Pelet A, Ruiz-Ferrer M, Sham PC, Shepherd IT, So MT, Sribudiani Y, Tang CS, van den Hout MC, van der Linde HC, van Ham TJ, van IJcken WF, Verheii JB, Amiel J, Borrego S, Ceccherini I, Chakravarti A, Lyonnet S, Tam PK, Garcia-Barceló MM, Hofstra RM. Whole exome sequencing coupled with unbiased functional analysis reveals new Hirschsprung disease genes. Genome Biol 2017; $18: 48$

19. Zhang Y, Huang H, Zhao G, Yokoyama T, Vega H, Huang Y, Sood R, Bishop K, Maduro V, Accardi J, Toro C, Boerkoel CF, Lyons K, Gahl WA, Duan X, Malicdan MC, Lin S. ATP6V1H Deficiency Impairs Bone Development through Activation of MMP9 and MMP13. PLoS Genet 2017:13:e1006481.

20. Colledge WH, Abella BS, Southern KW, Ratcliff R, Jiang C, Cheng SH, MacVinish LJ, Anderson JR, Cuthbert AW, Evans MJ. Generation and characterization of a delta F508 cystic fibrosis mouse model. Nat Genet 1995;10:445-52.

21. Zeiher BG, Eichwald E, Zabner J, Smith JJ, Puga AP, McCray PB, Capecchi MR, Welsh MJ, Thomas KR. A mouse model for the delta F508 allele of cystic fibrosis. J Clin Invest 1995;96:2051-64.

22. Peplow M. The 100,000 Genomes Project. BMJ 2016;353:i1757.

23. Dow LE, Lowe SW. Life in the fast lane: mammalian disease models in the genomics era. Cell 2012;148:1099-109.

24. Moulton MJ, Letsou A. Modeling congenital disease and inborn errors of development in Drosophila melanogaster. Dis Model Mech 2016;9:253-69.

25. Silverman GA, Luke CJ, Bhatia SR, Long OS, Vetica AC, Perlmutter DH, Pak SC. Modeling molecular and cellular aspects of human disease using the nematode Caenorhabditis elegans. Pediatr Res 2009;65:10-18.

26. Markaki M, Tavernarakis N. Modeling human diseases in Caenorhabditis elegans. Biotechnol J 2010;5:1261-76.

27. Pandey UB, Nichols CD. Human disease models in Drosophila melanogaster and the role of the fly in therapeutic drug discovery. Pharmacol Rev 2011;63:411-36.

28. Gama Sosa MA, De Gasperi R, Elder GA. Modeling human neurodegenerative diseases in transgenic systems. Hum Genet 2012;131:535-63.

29. Howe K, Clark MD, Torroja CF, Torrance J, Berthelot C, Muffato M, Collins JE, Humphray S, McLaren K, Matthews L, McLaren S, Sealy I, Caccamo M, Churcher C, Scott C, Barrett JC, Koch R, Rauch GJ, White S, Chow W, Kilian B, Quintais LT, Guerra-Assunção JA, Zhou Y, Gu Y, Yen J, Vogel JH, Eyre T, Redmond S, Banerjee R, Chi J, Fu B, Langley E, Maguire SF, Laird GK, Lloyd D, Kenyon E, Donaldson S, Sehra H, Almeida-King J, Loveland J, Trevanion S, Jones M, Quail M, Willey D, Hunt A, Burton J, Sims S, McLay K, Plumb B, Davis J, Clee C, Oliver K, Clark R, Riddle C, Elliot D, Eliott D, Threadgold G, Harden G, Ware D, Begum S, Mortimore B, Mortimer B, Kerry G, Heath P, Phillimore B, Tracey A, Corby N, Dunn M, Johnson C, Wood J, Clark S, Pelan S, Griffiths G, Smith M, Glithero R, Howden P, Barker N, Lloyd C, Stevens C, Harley J, Holt K, Panagiotidis G, Lovell J, Beasley H, Henderson C, Gordon D, Auger K, Wright D, Collins J, Raisen C, Dyer L, Leung K, Robertson L, Ambridge K, Leongamornlert D, McGuire S, Gilderthorp R, Griffiths C, Manthravadi D, Nichol S, Barker G, Whitehead S, Kay M, Brown J, Murnane C, Gray E, Humphries M, Sycamore N, Barker D, Saunders D, Wallis J, Babbage A, Hammond S, MashreghiMohammadi M, Barr L, Martin S, Wray P, Ellington A, Matthews N, Ellwood M, Woodmansey R, Clark G, Cooper J, Cooper J, Tromans A, Grafham D, Skuce C, Pandian R, Andrews R, Harrison E, Kimberley A, Garnett J, Fosker N, Hall R, Garner P, Kelly D, Bird C, Palmer S, Gehring I, Berger A, Dooley CM, Ersan-Ürün Z, Eser C, Geiger H, Geisler M, Karotki L, Kirn A, Konantz J, Konantz M, Oberländer M, Rudolph-Geiger S, Teucke M, Lanz C, Raddatz G, Osoegawa K, Zhu B, Rapp A, Widaa S, Langford C, Yang F, Schuster SC, Carter NP, Harrow J, Ning Z, Herrero J, Searle SM, Enright A, Geisler R, Plasterk RH, Lee C, Westerfield M, de Jong PJ, Zon LI, Postlethwait JH, Nüsslein-Volhard C, Hubbard TJ, Roest Crollius H, Rogers J, Stemple DL. The zebrafish reference genome sequence and its relationship to the human genome. Nature 2013:496:498-503.

30. Koster R, Sassen WA. A molecular toolbox for genetic manipulation of zebrafish. Adv Genomics Genet 2015;5:151-63.

31. Santoriello C, Zon LI. Hooked! Modeling human disease in zebrafish. J Clin Invest 2012:122:2337-43

32. Smith KA, Joziasse IC, Chocron $S$, van Dinther $M$, Guryev V, Verhoeven MC, Rehmann H, van der Smagt JJ, Doevendans PA, Cuppen E, Mulder BJ, Ten Dijke P, Bakkers J. Dominant-negative ALK2 allele associates with congenital heart defects. Circulation 2009;119:3062-9. 
33. Chapman AL, Bennett EJ, Ramesh TM, De Vos KJ, Grierson AJ. Axonal Transport Defects in a Mitofusin 2 Loss of Function Model of Charcot-Marie-Tooth Disease in Zebrafish. PLoS One 2013;8:e67276.

34. Zhang J, Wang C, Shen Y, Chen N, Wang L, Liang L, Guo T, Yin X, Ma Z, Zhang B, Yang L. A mutation in ADIPOR1 causes nonsyndromic autosomal dominant retinitis pigmentosa. Hum Genet 2016;135:1375-87.

35. Mangos S, Lam PY, Zhao A, Liu Y, Mudumana S, Vasilyev A, Liu A, Drummond IA. The ADPKD genes $p k d 1 \mathrm{a} / \mathrm{b}$ and $\mathrm{pkd} 2$ regulate extracellular matrix formation. Dis Model Mech 2010;3:354-65.

36. Majczenko K, Davidson AE, Camelo-Piragua S, Agrawal PB, Manfready RA, Li X, Joshi $\mathrm{S}, \mathrm{Xu}$ J, Peng W, Beggs AH, Li JZ, Burmeister M, Dowling JJ. Dominant mutation of CCDC78 in a unique congenital myopathy with prominent internal nuclei and atypical cores. Am J Hum Genet 2012:91:365-71.

37. Gnarra JR, Ward JM, Porter FD, Wagner JR, Devor DE, Grinberg A, Emmert-Buck MR Westphal H, Klausner RD, Linehan WM. Defective placental vasculogenesis causes embryonic lethality in VHL-deficient mice. Proc Natl Acad Sci U S A 1997;94:9102-7.

38. Haase VH. The VHL tumor suppressor in development and disease: Functional studies in mice by conditional gene targeting: NIH Public Access. 2005:564-74.

39. Hickey MM, Lam JC, Bezman NA, Rathmell WK, Simon MC. von Hippel-Lindau mutation in mice recapitulates Chuvash polycythemia via hypoxia-inducible factor2alpha signaling and splenic erythropoiesis. J Clin Invest 2007;117:3879-89.

40. van Rooijen E, Voest EE, Logister I, Korving J, Schwerte T, Schulte-Merker S, Giles RH, van Eeden FJ. Zebrafish mutants in the von Hippel-Lindau tumor suppressor display a hypoxic response and recapitulate key aspects of Chuvash polycythemia. Blood 2009;113:6449-60.

41. Kimmel CB, Ballard WW, Kimmel SR, Ullmann B, Schilling TF. Stages of embryonic development of the zebrafish. Dev Dyn 1995;203:253-310.

42. Kamei M, Isogai S, Pan W, Weinstein BM. Imaging blood vessels in the zebrafish 2010:27-54.

43. Langenau DM, Ferrando AA, Traver D, Kutok JL, Hezel JP, Kanki JP, Zon LI, Look AT, Trede NS. In vivo tracking of T cell development, ablation, and engraftment in transgenic zebrafish. Proc Natl Acad Sci U S A 2004;101:7369-74.

44. Vacaru AM, Unlu G, Spitzner M, Mione M, Knapik EW, Sadler KC. In vivo cell biology in zebrafish - providing insights into vertebrate development and disease. J Cell SCi 2014;127:485-95.

45. Arslanova D, Yang T, Xu X, Wong ST, Augelli-Szafran CE, Xia W. Phenotypic analysis of images of zebrafish treated with Alzheimer's gamma-secretase inhibitors. BMC Biotechnol 2010;10:24

46. Pardo-Martin C, Chang TY, Koo BK, Gilleland CL, Wasserman SC, Yanik MF. Highthroughput in vivo vertebrate screening. Nat Methods 2010;7:634-6.

47. Winter MJ, Redfern WS, Hayfield AJ, Owen SF, Valentin JP, Hutchinson TH. Validation of a larval zebrafish locomotor assay for assessing the seizure liability of early-stage development drugs. J Pharmacol Toxicol Methods 2008;57:176-87.

48. Moens CB, Donn TM, Wolf-Saxon ER, Ma TP, Tp M. Reverse genetics in zebrafish by TILLING. Brief Funct Genomic Proteomic 2008;7:454-9.

49. Varshney GK, Huang H, Zhang S, Lu J, Gildea DE, Yang Z, Wolfsberg TG, Lin S, Burgess SM. The Zebrafish Insertion Collection $(Z \ln C)$ : a web based, searchable collection of zebrafish mutations generated by DNA insertion. Nucleic Acids Res 2013;41:D861-4.

50. Doyon Y, McCammon JM, Miller JC, Faraji F, Ngo C, Katibah GE, Amora R, Hocking TD, Zhang L, Rebar EJ, Gregory PD, Urnov FD, Amacher SL. Heritable targeted gene disruption in zebrafish using designed zinc-finger nucleases. Nat Biotechnol 2008:26:702-8

51. Sander JD, Cade L, Khayter C, Reyon D, Peterson RT, Joung JK, Yeh JR. Targeted gene disruption in somatic zebrafish cells using engineered TALENs. Nat Biotechnol 2011;29:697-8.

52. Hwang WY, Fu Y, Reyon D, Maeder ML, Tsai SQ, Sander JD, Peterson RT, Yeh JR, Joung JK. Efficient genome editing in zebrafish using a CRISPR-Cas system. Nat Biotechnol 2013;31:227-9.

53. Nasevicius A, Ekker SC. Effective targeted gene 'knockdown' in zebrafish. Nat Genet 2000;26:216-20.

54. Nasevicius A, Larson J, Ekker SC. Distinct Requirements for Zebrafish Angiogenesis Revealed by a VEGF-A Morphant. Yeast 2000;1:294-301.

55. Rossi A, Kontarakis Z, Gerri C, Nolte H, Hölper S, Krüger M, Stainier DY. Genetic compensation induced by deleterious mutations but not gene knockdowns. Nature 2015:524:230-3.

56. Grunwald DJ, Streisinger G. Induction of recessive lethal and specific locus mutations in the zebrafish with ethyl nitrosourea. Genet Res 1992;59:103-16.

57. Solnica-Krezel L, Schier AF, Driever W. Efficient recovery of ENU-induced mutations from the zebrafish germline. Genetics 1994;136:1401-20.

58. Kettleborough RN, Busch-Nentwich EM, Harvey SA, Dooley CM, de Bruijn E, van Eeden F, Sealy I, White RJ, Herd C, Nijman IJ, Fényes F, Mehroke S, Scahill C, Gibbons R, Wali N, Carruthers S, Hall A, Yen J, Cuppen E, Stemple DL. A systematic genomewide analysis of zebrafish protein-coding gene function. Nature 2013;496:494-7.

59. Heintze J, Luft C, Ketteler R. A CRISPR CASe for high-throughput silencing. Front Genet 2013:4:1-6.

60. Perles Z, Moon S, Ta-Shma A, Yaacov B, Francescatto L, Edvardson S, Rein AJ, Elpeleg 0 , Katsanis N. A human laterality disorder caused by a homozygous deleterious mutation in MMP21. J Med Genet 2015;52:840-7
61. Armstrong GA, Liao M, You Z, Lissouba A, Chen BE, Drapeau P. Homology Directed Knockin of Point Mutations in the Zebrafish tardbp and fus Genes in ALS Using the CRISPR/Cas9 System. PLoS One 2016;11:e0150188

62. Hisano Y, Sakuma T, Nakade S, Ohga R, Ota S, Okamoto H, Yamamoto T, Kawahara A. Precise in-frame integration of exogenous DNA mediated by CRISPR/Cas9 system in zebrafish. Sci Rep 2015;5:8841.

63. Prykhozhij SV, Fuller C, Steele SL, Veinotte CJ, Razaghi B, Robitaille JM, McMaster CR, Shlien A, Malkin D, Berman JN. Optimized knock-in of point mutations in zebrafish using CRISPR/Cas9. Nucleic Acids Res 2018

64. Auer TO, Duroure K, De Cian A, Concordet JP, Del Bene F. Highly efficient CRISPR/ Cas9-mediated knock-in in zebrafish by homology-independent DNA repair. Genome Res 2014;24:142-53.

65. Komor AC, Kim YB, Packer MS, Zuris JA, Liu DR. Programmable editing of a target base in genomic DNA without double-stranded DNA cleavage. Nature 2016;533:420-4.

66. Gaudelli NM, Komor AC, Rees HA, Packer MS, Badran AH, Bryson DI, Liu DR. Programmable base editing of $A \bullet T$ to $G \bullet C$ in genomic DNA without DNA cleavage. Nature 2017:551:464-71.

67. Zhang Y, Qin W, Lu X, Xu J, Huang H, Bai H, Li S, Lin S. Programmable base editing of zebrafish genome using a modified CRISPR-Cas9 system. Nat Commun 2017:8:118.

68. Kim K, Ryu SM, Kim ST, Baek G, Kim D, Lim K, Chung E, Kim S, Kim JS. Highly efficient RNA-guided base editing in mouse embryos. Nat Biotechnol 2017;35:435-7.

69. Kim YB, Komor AC, Levy JM, Packer MS, Zhao KT, Liu DR. Increasing the genometargeting scope and precision of base editing with engineered Cas9-cytidine deaminase fusions. Nat Biotechnol 2017:35:371-6.

70. Kok FO, Shin M, Ni CW, Gupta A, Grosse AS, van Impel A, Kirchmaier BC, PetersonMaduro J, Kourkoulis G, Male I, DeSantis DF, Sheppard-Tindell S, Ebarasi L, Betsholtz C, Schulte-Merker S, Wolfe SA, Lawson ND. Reverse genetic screening reveals poor correlation between morpholino-induced and mutant phenotypes in zebrafish. Dev Cell 2015;32:97-108.

71. Larson MH, Gilbert LA, Wang X, Lim WA, Weissman JS, Qi LS, LS Q. CRISPR interference (CRISPRi) for sequence-specific control of gene expression. Nat Protoc 2013;8:2180-96

72. Gilbert LA, Larson MH, Morsut L, Liu Z, Brar GA, Torres SE, Stern-Ginossar N, Brandman O, Whitehead EH, Doudna JA, Lim WA, Weissman JS, Qi LS, LS Q. CRISPRmediated modular RNA-guided regulation of transcription in eukaryotes. Cell 2013;154:442-51

73. Heman-Ackah SM, Bassett AR, Wood MJ. Precision Modulation of Neurodegenerative Disease-Related Gene Expression in Human iPSC-Derived Neurons. Sci Rep 2016:6:28420

74. Mandegar MA, Huebsch N, Frolov EB, Shin E, Truong A, Olvera MP, Chan AH, Miyaoka Y, Holmes K, Spencer Cl, Judge LM, Gordon DE, Eskildsen TV, Villalta JE, Horlbeck MA, Gilbert LA, Krogan NJ, Sheikh SP, Weissman JS, Qi LS, So PL, Conklin BR, LS Q, PI S. CRISPR Interference Efficiently Induces Specific and Reversible Gene Silencing in Human iPSCs. Cell Stem Cell 2016:18:541-53.

75. Liu J, Zhou Y, Qi X, Chen J, Chen W, Qiu G, Wu Z, Wu N. CRISPR/Cas9 in zebrafish: an efficient combination for human genetic diseases modeling. Hum Genet 2017; 136:1-12.

76. Zhang Y, Ear J, Yang Z, Morimoto K, Zhang B, Lin S. Defects of protein production in erythroid cells revealed in a zebrafish Diamond-Blackfan anemia model for mutation in RPS19. Cell Death Dis 2014:5:e1352.

77. Norton LE, Layman DK. Leucine regulates translation initiation of protein synthesis in skeletal muscle after exercise. J Nutr 2006;136:533S-7.

78. Payne EM, Virgilio M, Narla A, Sun H, Levine M, Paw BH, Berliner N, Look AT, Ebert BL, Khanna-Gupta A. L-Leucine improves the anemia and developmental defects associated with Diamond-Blackfan anemia and del( $5 q)$ MDS by activating the mTOR pathway. Blood 2012;120:2214-24.

79. Qin A, Cheng TS, Pavlos NJ, Lin Z, Dai KR, Zheng MH. V-ATPases in osteoclasts: structure, function and potential inhibitors of bone resorption. Int J Biochem Cell Biol 2012:44:1422-35

80. Li YP, Chen W, Liang Y, Li E, Stashenko P. Atp6i-deficient mice exhibit severe osteopetrosis due to loss of osteoclast-mediated extracellular acidification. Nat Genet 1999;23:447-51.

81. de Vrieze E, Sharif F, Metz JR, Flik G, Richardson MK. Matrix metalloproteinases in osteoclasts of ontogenetic and regenerating zebrafish scales. Bone 2011;48:704-12.

82. Lopes SS, Lourenço R, Pacheco L, Moreno N, Kreiling J, Saúde L. Notch signalling regulates left-right asymmetry through ciliary length control. Development 2010;137:3625-32

83. Sheridan E, Wright J, Small N, Corry PC, Oddie S, Whibley C, Petherick ES, Malik T, Pawson N, McKinney PA, Parslow RC. Risk factors for congenital anomaly in a multiethnic birth cohort: an analysis of the Born in Bradford study. Lancet 2013:382:1350-9.

84. Corry PC. Consanguinity and prevalence patterns of inherited disease in the UK Pakistani community. Hum Hered 2014;77:207-16.

85. Kara B, Köroğlu Ç, Peltonen K, Steinberg RC, Maraş Genç H, Hölttä-Vuori M, Güven A, Kanerva K, Kotil T, Solakoğlu S, Zhou Y, Olkkonen VM, Ikonen E, Laiho M, Tolun A. Severe neurodegenerative disease in brothers with homozygous mutation in POLR1A Eur J Hum Genet 2017;25:315-23.

86. Philips AK, Pinelli $\mathrm{M}$, de Bie $\mathrm{Cl}$, Mustonen A, Määttä $\mathrm{T}$, Arts $\mathrm{HH}$, Wu K, Roepman $\mathrm{R}$, Moilanen JS, Raza S, Varilo T, Scala G, Cocozza S, Gilissen C, van Gassen KL, Järvelä I. 
Identification of C12orf4 as a gene for autosomal recessive intellectual disability. Clin Genet 2017;91:100-5.

87. Raymond FL, Whibley A, Stratton MR, Gecz J. Lessons learnt from large-scale exon re-sequencing of the X chromosome. Hum Mol Genet 2009;18:R60-R64.

88. Deciphering Developmental Disorders S. Large-scale discovery of novel genetic causes of developmental disorders. Nature 2015;519:223-8.

89. Wright CF, Fitzgerald TW, Jones WD, Clayton S, McRae JF, van Kogelenberg M, King DA, Ambridge K, Barrett DM, Bayzetinova T, Bevan AP, Bragin E, Chatzimichali EA, Gribble S, Jones P, Krishnappa N, Mason LE, Miller R, Morley KI, Parthiban V, Prigmore E, Rajan D, Sifrim A, Swaminathan GJ, Tivey AR, Middleton A, Parker M, Carter NP, Barrett JC, Hurles ME, FitzPatrick DR, Firth HV, study DDD; DDD study. Genetic diagnosis of developmental disorders in the DDD study: a scalable analysis of genome-wide research data. Lancet 2015:385:1305-14.

90. Deciphering Developmental Disorders S. Prevalence and architecture of de novo mutations in developmental disorders. Nature 2017:542:433-8.

91. Beaulieu CL, Majewski J, Schwartzentruber J, Samuels ME, Fernandez BA, Bernier FP, Brudno M, Knoppers B, Marcadier J, Dyment D, Adam S, Bulman DE, Jones
SJ, Avard D, Nguyen MT, Rousseau F, Marshall C, Wintle RF, Shen Y, Scherer SW, Friedman JM, Michaud JL, Boycott KM; FORGE Canada Consortium. FORGE Canada Consortium: outcomes of a 2-year national rare-disease gene-discovery project. Am J Hum Genet 2014;94:809-17.

92. Dawkins HJS, Draghia-Akli R, Lasko P, Lpl L, Jonker AH, Cutillo CM, Rath A, Boycott KM, Baynam G, Lochmuller H, Kaufmann P, Le Cam Y, Hivert V, Austin CP. International Rare Diseases Research C. Progress in Rare Diseases Research 2010-2016: An IRDiRC Perspective. Clin Trans/ Sci 2018;11:11-20.

93. Ramoni RB, Mulvihill JJ, Adams DR, Allard P, Ashley EA, Bernstein JA, Gahl WA, Hamid R, Loscalzo J, McCray AT, Shashi V, Tifft CJ, Wise AL; Undiagnosed Diseases Network. The Undiagnosed Diseases Network: Accelerating Discovery about Health and Disease. Am J Hum Genet 2017;100:185-92.

94. Wangler MF, Yamamoto S, Chao HT, Posey JE, Westerfield M, Postlethwait J, Hieter P, Boycott KM, Campeau PM, Bellen HJ, Bellen HJ; Members of the Undiagnosed Diseases Network (UDN). Model Organisms Facilitate Rare Disease Diagnosis and Therapeutic Research. Genetics 2017;207:9-27. 